\title{
Opinions of Theorists about Public Finance and Their Reflection on the Development of the Economy and the State
}

\author{
Refik Kryeziu*
}

RESEARCH

ARTICLE

\begin{abstract}
ARTICLE INFO
Submitted : 22.02.2021

Revised : 14.05.2021

Accepted : 10.06.2021

Available : 30.06 .2021

iThenticate similarity

score: $8 \%$

JEL classification:

$\mathrm{A} 10, \mathrm{G} 00, \mathrm{H} 2 \mathrm{O}, \mathrm{H} 2$,

$\mathrm{H} 60$

Keywords:

Economy, public

finances, taxes, budget, public debt

A B S T R A C T

As a science of economics, public finance uses theories and methods to explain government programs and policies that flow in this area. The paper analyses the views of contemporary theorists, aiming to show how economists at different times gave their opinions on the categories of public finance. The theorists with the most popular views on modern finance and economics are Barro, Zuckerman, Friedman, Samuelson, Tanzi, Hyman, Lecciseti, Rosen, Heller, Meltzer, Perotti, Aleksina, Dickinson, Blanchard, Krugman, Corsetti, Rubin, Stiglitz and others. As an object of interest, we find English authors such as Hobbes, Locke, Hume, Ricardo and Mill (1985). In Germany, Malchus, later K. H. Rau, theorists such as Lorenz von Stein, Albert Schafle, Adolf Wanger and others, made a great contribution to the development of public finance. In Italy, we singled out Bandini, Pascoli, Brogi, who contributed to the unified tax system, while Pascoli and Brogi, regarding the tax system according to yields and customer tax. Cossi, Pantheon, Flore, De Viti de Marco and Graziani addressed the relationship between those who pay taxes and the state that provides public services. In France, R. Stourm also contributed to the budget and budget problems, $P$. Leroy-Beaulieu contributed to the problems of income, expenditure and tax principles against any progressive measures in the imposition of the tax, as well as the theorist Gaston Jèze. In the U.S., in addition to theorists like F. Seligman and Adams, we also notice Keynes's opponents, who were the economists Friedman and Meiselman.
\end{abstract}

Cite this article as: Kryeziu, R. (2021). "Opinions of Theorists about Public Finance and Their Reflection on the Development of the Economy and the State", International Journal of Public Finance, 6(1), 47-62.

Assist. Prof. PhD., University "Kadri Zeka”, Faculty of Economics, Gjilan, Republic of Kosovo, ORCID: 0000-0001-8628-6166, refik.kryeziu@uni-gjiln.net 


\section{Introduction}

Many economists and financiers from different countries have given their views and opinions on the issues, concepts, goals, definitions, functions, and public finances. The authors share their opinions in times and circumstances of changes in economic, political and financial processes. The results show that their opinions represent a significant contribution to the development of public finances.

In this context, the work of many theorists devoted to public finance speaks to the importance and role that this sphere has, both for governments and the state. It is characteristic and special that their contributions are always current even though great changes have been made.

In the paper, we will present the specifics where theorists have dealt with different fields. Some have addressed the issue of taxes and the tax system, some fiscal policies in general, tax system reforms, some public revenues and expenditures, and participation in Gross Domestic Product. The other group of thinkers in their works address the budget, budget system, deficit, public debt and other issues.

In this paper, we will address to what extent the opinions of theorists influence the theoretical and practical aspects in the development of public finances. So, in addition to the theoretical aspect, in most cases their ideas even today find support in the practical aspect where they are also current, find support and serve the governments of the states in the development of public finances.

\section{Literature Review}

The science of public finance from economic science began to develop from the first half of the XIX century. In contrast, theories about this issue began to be explored from 1930 to continue with contemporary theorists, who contributed to the study of this field, to strengthen the issue of public finances by treating it more from a macroeconomic point of view.

Thus, using the standard principles of economic analysis to understand how total output (GDP) is determined is the period of birth and development of the new classical macroeconomics. Nowadays, we see the nature of economic analysis in various spheres, such as in the field of public finance, international trade and labour economics (Henderson, 2007).

We find public finances as the object of interest of English authors from the XVIth century to the XIXth century. The most famous representatives are Hobbes, Locke, Hume, Ricardo and Mill (Jelcic, 1985).

The beginning of the XXth century represents a new era in capitalist economics. Various thoughts were presented for financial problems, contributing to new views on finance and the modern capitalist economy. 
The Italians should be mentioned as Eiandin, Nitin, the English H. Dalton, ME, Robinson, the French B. Nogarin, L. Trobasin, H. Lauffeuburgerin, the Germans W. Gerlofin, Heckelin, Lotzin, Ritschelin, Tarhalin and B. Mollin, the Swede E. Lindalin, Swiss A. Amon, Czech Enklis and Hungarian Foldes (Filipovic, 1965).

In Germany, Malchus and later K. H. Rau made a significant contribution to the development of public finances. While Malchus made the division of taxes into subjective (personal) and objective (real), and maintained an attitude towards the views of the principle of the same tax victims, $\mathrm{K}$. $\mathrm{H}$ Rau is among the first to elaborate the meaning of taxes theoretically. Later, in the second half of the XIXth century, Lorenz von Stein, Albert Schafle, Adolf Wanger and others appeared in Germany.

At the beginning of the XVIII century, prominent theorists appeared in Italy who contributed to the study of finance, especially Bandini, Pascoli, Brogi, etc. Bandini was committed to a unified tax system, demanded the introduction of a tax, land tax. Pascoli and Brogi were committed to the functioning of the tax system according to yields (production), land and capital. These are for the customer tax, excluding the food tax.

In the second half of the XIXth century, Cossi, Pantheon, Flore, De Viti de Marco and Graziani contributed with their work, according to which financial activity reflects acts of exchange between those who pay taxes and the state that provides public services. According to this theory, finances do not represent a consumption phenomenon but an exchange phenomenon, equivalent between the state and citizens. As can be seen, these theorists have included the tax system and the tax burden in their treatment.

In addition to these, in France came theorists called physiocrats, where only agriculture gives yields, so it must be taxed. The representatives of the physiocrats are F. Quesnay, who was consistent in applying a tax on land yields since yields are the original income, therefore it is the only possibility of taxes, Mirabeau was against a tax and supported the idea that the tax is applied to other products.

Regarding the development of public finances in France, a contribution was given by R. Stourm, oriented towards the study of budget and budget problems, P. Leroy-Beaulieu, elaborated the issue of income, expenditures and tax principles, he has been against any progressive measure in tax setting as well as the theorist Gaston Jeze who represents the modern direction of science over public finance.

While the economy in the U.S. was developed earlier than in other countries, with theoretical works, economists in this country traditionally appeared later than in other countries. Among the most famous American theorists are F. Seligman and Adams, who are known for handling tax charges in scientific circles.

It is a characteristic that the beginning of the twentieth century represents a new era in capitalist economics and we have the emergence of contemporary 
theorists, who in their studies devoted themselves to the problem of public finances. They applied mathematical and statistical methods, among the best known are: Barro, Zuckerman, Friedman, Samuelson, Tanzi, Hyman, Lecciseti, Rosen, Heller, Meltzer, Perotti, Aleksina, Dickinson, Blanchard, Krugman, Corsetti, Rubin, Stiglitz and others.

Many Croatian authors have also dealt with aspects of the treatment of public finances, starting with Adalberta Barcia, c. XVII to Bozidar Jelçic, c. XX (Brajshori, 2014).

Richard Musgrave presents the comprehensive theory of the state and the public tax based on the perfectly competitive model. It is based on the notion of the objective of the economic system and the role of government in improving the wellbeing of individuals or families. Musgrave supports the idea that the success of taxation and government in a market economy is seen in three separate branches: allocation (efficiency), distribution and macroeconomic stability (Musgrave, 1959)

Public finance as a science studies issues related to the economic base and government activities. An important objective of analysis and study is to understand the impact of government spending, regulations, taxes, and borrowing to invest (Hyman, 2010).

Conditionally speaking, public finances are identified with revenues (mainly taxes), expenditures, budget and public debt, while, in terms of their growth and development, they depend on the degree and level of economic development of the country.

Numerous theorists dealing with public finances have given different opinions in policy-making, while the goals and objectives are the same. In this respect, government policy is determined concerning the manner of taxation and the determination of public expenditure, commonly referred to as public finance.

Instead, the main problems related to the use of real resources and spending policies, and some authors prefer to be defined by the term public sector economics (Rossen, 2003).

Therefore, based on the functions and goals of state finances, the term public finance is used, where we think it is more appropriate and adequate.

\section{Methodology}

The paper focuses on the research we have done, based on the opinions of many authors, who in their scientific career addressed the issue of public finances from a theoretical point of view, which in most cases have found a place and have been implemented in practice. While some thinkers have dealt with several areas of public finance, and some addressed one of them, it is important to see that their contribution has reflected and influenced the evolution and development of public finance over 
time, but that their scientific contributions have reflected on the development of the economy and the state in general.

During the realization of the paper, we will use different research methods, such as research, comparison, data analysis, based on the implementation of fiscal policies that enable the realization of government objectives to conclude that public finances affect the increase of social welfare of the population, economic development, etc. We will apply the qualitative method, where the paper is based on empirical analysis of the study, where data are collected from secondary sources, mainly from scientific and professional literature, which includes perhaps 68 theorists using 38 sources of university, scientific, professional literature, reports, internet, etc., which address the issue of public spending, taxes, revenues, budget, public debt, etc.

On the other hand, the paper is enriched by the written opinions of the most eminent authors coming from different countries. In most cases, they have concluded that public finances are a key and strategic factor in developing the economy and the state.

\section{Taxes and the Tax System as the Main Instruments in the Formation of Budget Revenues}

Many economists who have dealt with the treatment of public finances have focused the study on taxes, the tax system and the factors that enable their functioning.

Below, according to thinkers, we give the definitions of taxes: Tax is that part of the property that every citizen gives to the state, while the rest can be secured (Montesquieu); Tax is part of the means that the citizens pay to the state to compose their share of the high price of public services, which they will spend (De Viti de Marco); Taxation is the giving of money, which the state collects from individuals based on its sovereignty, without direct consideration (Gaston Jese); According to Adolph Wagner, taxation is a mandatory provision of economic units, which with one part serve to cover common social needs, while with the other part for the distribution of national income (Komoni, 2008).

John Stuart Mill is limited to the issue of taxation and the principle of tax equality. His opinion was for the exemption of the minimum subsistence tax, while from the point of view of the tax rate policy, he is against the imposition of progressive tax rates.

Free market development contributor David Ricardo has dealt primarily with tax system theory in terms of tax burden-sharing. He has studied in detail the phenomenon of tax burdens and the consequences it has for capital formation, employment and productivity growth (Filipovic, 1959). 
While Thomas Hobbes claims that fair tax charging can be most easily accomplished by applying indirect taxes. According to him, consumption reflects the economic strength of citizens, while John Locke argued and defended the advantages of direct taxes, such as agriculture, cadastre, etc.

While Hume supports the view that the tax liability should be determined depending on the benefits it has from the state, Adam Smith is committed to reviewing tax principles and tax transfer.

From these opinions, we derive the best definition of taxes and the tax system: Taxes are fiscal instruments through which natural and legal persons pay to the state, regardless of individual and collective benefits, an income of any form, wealth and economic power.

Richard Musgrave introduces a comprehensive theory of state and public taxation based on the perfectly competitive model. It is based on the notion that the objective of the economic system and the role of government is to improve the wellbeing of individuals or families, as they define themselves.

The proper roles of government in a market economy in this scheme fall into three separate branches, such as allocation (efficiency), distribution and macroeconomic stability (Musgrave, 1959).

In democratic societies, the political process plays a crucial role in shaping the complex tax systems we respect. Many authors have explained how the interaction of the private economy and the political process determines the current structure of the tax system (Hettich and Winer, 1999).

It is worth noting that the theorists who have engaged in determining tax policy and other issues, among the best known is Irving Fisher, who opposed the taxation of conventional income, favouring its replacement with a consumption tax. Today's economists support Fisher's reasoning in imposing consumer taxes (Henderson, 2007).

Thus, in the practical life of public finances, value added tax is a consumption tax, currently, this is applied by more than 121 countries, where we believe that other countries will continuously use this type of tax.

\section{Contributions of Thinkers about Public Spending and Their Impact on the Economy}

Various thinkers, regarding the development and functioning of public finances, in their works, have given and continue to give valuable contributions to the issue of public spending. Among the most prominent thinkers who have dealt with public spending is Jean Baptiste Say, who claims that "public spending is a net loss for the economy at the national level, as well as for the contributors who supply state funds, because public spending is covered by taxes, which in fact absorb their funds from the 
sphere of production and are used by the state for the needs of luxury". According to D. Ricardo and G. Jese, finances have a distribution function; therefore, they should deal with the distribution, division of burden or volume of public expenditures among citizens based on their solvency.

Gaston Jese distinguishes the reasons for the increase in public expenditures: a) as fictitious causes, which do not increase the tax liability and b) real causes of public expenditures (Jelçiç, 1985).

An important place on public spending belongs to the well-known theorist Adolf Wagner who says that the increase in public expenditure is a continuous increase in the activity of the state (Wagner, 1890).

Regarding the role and impact of public spending on state intervention in the economy, the well-known thinker John Maynard Keynes played an important role. According to him, the state, through public expenditure can develop and must intervene in the economy, which aims to alleviate economic problems, reduce unemployment and avoid the economic crisis. This view is still supported and applied in many countries globally, although many theorists have opposed it.

Among Keynes's opponents in this matter were economists such as Friedman and Meiselman, who opposed the effectiveness of the stabilization tax policy (later known as Keynesian) compared to monetary policy analysis made in the United States in 1897.

However, the ensuing controversy (which no one can say has been extinguished) between fiscalists and monetarists has at the same time served to clarify and qualify the effectiveness and objectives of both policies (Leccisoti, 2000). Many theorists, authors of texts on finance, began to orient themselves from the study of economics and financial policy measures in the field of economic and social life, such as employment, price levels, economic growth, changing the structure of the economy, in the field of foreign trade, revenue redistribution and allocation of funds to regional development (Jelçiç, 1985).

In today's economic policy discussions, it can be seen that the macroeconomics of the Keynesians and the New Classics leads to different conclusions about the three economic policies that were often suggested e.g., during the 1992 U.S. election campaign:

1. A temporary tax reduction for the middle class;

2. A temporary revival of the investment loan tax, and

3. Expenditure policy by the Federal Reserve, e.g., increase in the money supply rate and decrease in price reductions (Henderson, 2007). 
Based on these three factors, the governments of different states in their programs for the economy are committed to orient the policies in the development of investments, employment, etc. through public expenditures.

Various economists, indirectly and perhaps without the intention of increasing public spending, devoted themselves to this sphere, popularizing economic concepts. They offered their theoretical reasoning that it is appropriate to make government interventions in the economy (Tanzi Vito).

In these cases, governments need to commit to fiscal stability. From this, we must take into account the factors that affect the economy, such as the role of the state in the economy, for the increase of expenditures and revenues, where the size of the public sector has an important role (Lundberg, 1977). Regarding the influence and growth of the public sector, Wagner's Law is known, which in the policy of functioning of public finances can often be interpreted as follows: if per capita income increases, the level of public spending should also increase as part of GDP (Jelçiç, 1985).

In public finance policy, theorists also paid attention to the system of financing and financial compensation. Regarding the functioning of the financial compensation system (Henner A. Kleinewefers/Regula Pfister, 1978), they see functional links between budget organizations. In their study, they present the policies and the financing system. On the other hand, they prove that this system, responds to the manner of the administrative organization of the state, where the vertical and horizontal system of financing operates.

To develop public expenditures and their role in the economy, it is necessary to make changes, reforms in the orientation of public expenditures, orienting the means in the development of capital investments and financing specific sectors of the economy.

\section{Tax Reforms in the Function of Economic Development}

In order for the effects of spending and taxes to reflect on economic development, different governments must constantly make changes, policy reforms, the tax system, and tax rates. In national economies, the most pronounced reforms were applied to transition countries in the '90s. These changes have been made more in some states and some less. Thanks to tax changes in centralized economies, individuals and legal entities reacted hostilely to the introduction of a new tax system.

In fiscal policy, tax reforms are related to the reduction of tax rates, the expansion of the tax base and their reflection on economic development. Experiences have shown that tax reforms have affected the growth of National Revenues, economic growth, increased employment, increased budget revenues, capital investments, increased consumption, increased welfare of citizens, stimulating the private sector, especially in certain branches of the economy, depending on the 
measures and policies undertaken and applied by the governments of different countries (Kryeziu, 2014).

On the other hand, countries that apply lower taxes on corporate profits are more likely to attract foreign direct investment. Therefore, fiscal reforms in contemporary countries create ideal conditions for foreign investors (Madura, 2004).

Regarding the impact of fiscal reforms, through the reduction of tax rates, the effects are reflected in the attraction of foreign investment. Countries that apply lower taxes provide opportunities to attract foreign direct investment because international corporations find their market interest as a result of lower tax rates compared to those they have, in the country of origin (Kryeziu, 2014).

In this regard, for many reasons, radical reforms in fiscal policy must be set in motion in the long run, which would bring an ideal situation for generations, where the state will function approximately in accordance with the optimal economy (Tanzi, 2005).

On the other hand, the harmonization of fiscal policies between states should be approximated, but this policy seems to be ignored, where we can understand both sides of the medal. Applying tax harmonization between countries would help develop economic relations between countries, the reason why this issue is no longer realized is easy to understand, states want to have tax autonomy that suits the policies and specifics of their economies, therefore, in the near future, we expect to have movements in favour of the tax harmonization process starting between the countries of the region, to continue wider.

\section{Issues of the State Budget and Debt Deficit}

The state budget is a project, i.e., a systematic financial statement of all revenues and expenditures for a period of one year. The budget represents the government program approved by law by the state parliament, which provides budget revenues and sets the maximum expenditure limit.

One of the issues that can present difficulties, problems, and the economic crisis in some countries is the high budget deficit, repeated from year to year. To better consider the issue of debt, we must take into account the fact that different countries face the deficit and the opposite with the budget surplus.

Economists in their study who have addressed the problem of deficit and surplus are also D. I. Trotman -Dickinson (1996).

In the simplest sense, it is explained as follows: The change from the balanced budget when the financial means flow with the increase of expenditures is the deficit and, conversely, the surplus when the revenues are greater than the expenditures (Hyman, 2010). 
The biggest problems can be caused by high deficit and public debt, above the norms set under the Maastricht Treaty, the consequences are observed in fiscal instability.

The biggest deficit problem is the large government debts that occur in many countries. We had the case of Greece and Ireland in 2010, whereas a result of the high deficit, the economic and financial crisis was caused, wherein some eurozone countries and elsewhere it affected more and somewhere less.

Thus, in 2009 the United Kingdom reached a massive budget deficit of 11.5\%, Spain 9.4\%, Greece 8.1\%, France 7.8\%, Ireland 9.9\%, etc.

From 2007 when the global crisis began and until today a good part of the countries of the world applied, some more and some less, coercive policies, having as a primary objective the increase of fiscal revenues, the reduction of public expenditures and labour market discipline (Muço, 2021).

We have big problems in budget policy when from year to year, governments face a high budget deficit that continues for a long time, causing consequences in the economy and fiscal policy. Also, recurrent deficits can reduce the standard of living of future generations, contributing to reduced investment and lower economic growth (Nyman, 2010).

David Ricardo also gave an opinion on the budget deficit and the impact on the economy, who treats the relation of the impact of financing government debt among generations, whereby he says that they are equivalent, where the form of government financing is irrelevant and therefore it is called the Ricardian model, but he himself was sceptical about his theory. Barro also expresses the equivalent phenomenon between debt and generations. According to him, the reduction of taxes is associated with an increase in the budget deficit, but that does not cause an increase in consumption, it will not have any expansionary effect on the economy.

In their studies, Alex Cukierman and Allan H. Meltzer have identified the economic factors that lead to the emergence of large debt and budget deficit. Based on this, they give the opinion that the big debt is for the following reasons: due to the spread of wealth distribution (human and inhuman) of all individuals; due to the high rate of technical progress and due to the return on capital (Cukierman \& Meltzer, 1989).

Then, the higher deficit does not cause the interest rate to rise because the savings increase by the same amount, the overall effect is zero, having no negative impact on investment (Krajewski \& Mackiewicz, 2005).

On the other hand, Bob Rubin and Allen Sinai have pointed out that the major negative consequences of a persistent budget deficit occur very suddenly (Orszag \& Pechman, 2004). 
The well-known researchers Cukierman and Meltzer (1989), regarding the deficit, developed the theory that focuses on the generational aspect and debt redistribution. They argue that there are limitations to individuals, they would like to transfer resources from future generations to finance them. Based on this explanation, Cukierman and Meltzer argue that deficit growth and economic growth rate are based on income distribution or the trending expectation for the life expectancy of the population to increase, where, as a result, heirs will lead to large deficits. (Hung Chiat, 2003).

Authors such as Roubini and Sachs (1989), Grilli, Masciandaro, and Tabellini (1991) have researched political economy, dealing with the effects of the budget deficit associated with empirical results.

These authors studied the various effects of debt on the U.S. government, while in their studies, they emphasize the need to implement fiscal rules for OECD countries (Alesina \& Perotti, 1995).

\section{Public Debt, Its Importance and Dilemmas About It}

The state always has demanded financial means, governments need them for investments in building infrastructure and strategic projects. As a result of these needs, governments may spend more money than they generate their revenues. Therefore, governments provide funds through debt from domestic and foreign debt as a source of funds.

Public debt is one of the non-fiscal instruments that are part of revenue generation for financing the budget deficit and implementing strategic projects.

In addition to many economists, Robert Barro, who's an additional contribution with his work, has also dealt with public debt, proposing and disseminating the theory to minimize the excessive tax burden on society over time (Barro, 1979).

To some economists, it may seem unclear why governments are forced to borrow even when budget revenues are roughly the same as expenditures. In some cases, it may be because governments are obliged to pay off previously taken debts, so states go into debt even when they do not need the funds to invest.

In the practice of public finance science, it is difficult to find an area that is so much debated in conflicting ways between the parties, the government on the one hand, and the public on the other.

While David Hume (1777) was a great opponent of public debt, on the contrary, more than 100 years later, Carl Dietzel (1855) has a different view, at the same time, he strongly states and supports the entry of the state into debt. Economist Rosen also talks about the phenomenon of public debt, according to which we have a redistribution of the tax burden over time across generations. This has also been 
argued by Barro, when the government borrows, the members of the older generation realize that the heirs will be worse (Rosen, 2003).

Based not only on this view, but also on practical life, Hume's view falls short because all countries in the world except Singapore apply public debt, which is a source of revenue for financing the budget deficit and investing in capital projects.

In the simplest sense, borrowing enables the provision of funds to finance government expenditures. This means that in budget deficits, we have low taxes for current citizens, but that part of the tax revenue is paid by future generations, which is used to pay interest on debt, instead of providing services for governors (Hyman, 2010).

Under the assumption that some typical features of public debt analysis, as such, can be excluded, this shifts the tax burden to future generations, whereby the Barro model singles out the reallocation of generational resources as a reason for issuing public debt.

According to this theory, the effects and policy of public debt from migration so far is ignored, this best suits a closed economy. The government, according to him, should finance a certain amount of expenditures in each period through the taxation of current revenues and the increase of public debt, based on two factors, the composition of taxes and the level of government expenditures, influenced by exogenous factors (Hung \& Chiat, 2003).

On the other hand, in the question posed by Rosen; to tax or borrow, he reflects the data of debates whether, from various influencing factors, to cause an increase in public or government spending, they should be financed by raising taxes or increasing borrowing? At the same time, it leaves the opportunity to discuss whether the choice should be made between debt or taxes, which is also one of the most important problems in the field of public finance (Rosen, 2003).

An important contribution also comes from the conventional point of view, according to which government debt stimulates aggregate demand and economic growth in the short run and promotes the reduction of capital and national income in the long run. (Mankiw, 1998).

On the other hand, Sheikh et al. (2010) studied the impact of domestic debt on economic growth in Pakistan. The methodology used was that of OLS for the period 1972-2009. Their study showed that the domestic debt stock positively impacted economic growth in Pakistan (Sheikh et al., 2010).

In our opinion: should the government provide financial means through public debt or not, we think that in the public finance policy we should attach the debt management policy. If debt assets are well managed and utilized, have positive effects on economic development and increase welfare, the government should enter into public debt, while otherwise, if these assets are not well managed, the consequences 
for governments and the state will be in the future, then the government should reduce its public debts.

\section{Conclusion}

In this paper, the opinions of the most famous theorists are reflected, who in various forms gave their contributions to the development of public finances, economy and state.

In this regard, after reviewing the scientific literature, books and scientific papers, we have managed to identify some of the opinions of the most prominent economists and financiers who have made significant contributions to the development of public finances.

What characterizes the work with theorists is that we have found that in their studies they gave their contributions, addressing the categories of public finance, some of them with more categories and some with less.

Taking into account the views of theorists on public finances, we have found that they show arguments and that from a theoretical point of view they made a great contribution to be applied in practice about public finance developments regardless of the changes that occur in both economic and political spheres.

We observe differences and similarities among different economists about their views on public finance developments. Dilemmas and controversies, namely differences in their points of view are significant on the issue of public debt, often raising the question of whether governments should enter or not enter into debt.

At the end of the paper, we emphasize that not only the theorists mentioned in this paper, but also others, in their various ways contributed, at the same time they are scientific and professional messages to further influence the development of public finances. 


\section{References}

Abuselidze, G. (2020). "Optimality of Tax Policy on the Basis of Comparative Analysis of Income Taxation", European Journal of Sustainable Development, 9(1): 272-293.

Alexina, A., \& Perotti, R. (1995). Fiscal Expansions and Adjustments in OECD Countries, June 1995, published in October 1995.

Barro, R. (1979). "On the determination of the public debt", Journal of Political Economy 87(5): 940-971.

Bonzu S. (2018). The Macroeconomics of Fiscal Policy in Sierra Leone: An Empirical Investigation of Fiscal Sustainability, Fiscal Policy Shocks, and the Tax Smoothing Hypothesis. Royal Holloway, University of London.

Brkić, I. (2020). The relationship between economic freedom and economic growth in eu contries. Thesis PHD, Universitat Jaume-i.

Brajshori, B. (2014). Public Finances, 2014, page 30, Pristina.

Cukierman, A, \& Maltzer, A. (1989). Political Theory of Government Debt and Deficits in a Neo-Ricardian Framework, 79, 713-732.

Case, K. (2008). "Musgrave's vision of the public sector: the complex relationship between individual, society and state in public good theory", Journal of Economics and Finance, Springer; Academy of Economics and Finance, 32(4), 348-355.

Ermano, P.(2011). "Voice regarding progressive taxation", Problemy Polityki Społecznej, $16,39-57$.

Filipovic, H. (1965). Finance Science, Pristina.

Filipoviç, H. (1976). Science on Finance, Pristina.

Henderson, D.(2007). Classics of Economic Thinking, from the beginning to the present day, 66-185.

Hettich, W., \& Winer, S. (1988). "Economic and Political Foundations of Tax Structure", American Economic Review, 78: 701-712.

Hung, D., \& Chiat, C. (2003). Intertemporal excess burden, bequest motives and the budget deficit, Washington DC 20433, USA.

Hyman, D. (2010). Public Finance, Contemporary Application of Theory to Policy, Copyright 2010 Cengage Galasso Learning. North Carolina State University, USA.

Profeta P. (2002). "The political economy of social security: a survey", European Journal of Political Economy, 18(1), 1-29. 
Lundberg, E. (1977). Inflation Theory and Anti-Inflation Policy. Proceedings of a Conference held by the International Economic Association at Saltsjöbaden, Sweden.

Lici, E. Dika I.(2016). “Empircal evince of political budget cycle: Case of Albanian budget revenue", International Journal of Economics, Commerce and Management United Kingdom. IV (11), 59- 67.

Jelçiç, B. (2001). Public Finances, Zagreb.

Jelçiç, B. (1985). Science on Finances and Financial Law, Pristina.

Kleinewesfer, H.,\& Pfifer, R.(1978). Die Schweizer Wolksvwirtschaft Verlaghauber Freundfeld.

Muço, K. (2017). Public Debt and Economic Growth, Panorama, 19 February 2017, http://shtetiweb.org/2017/02/19/borxhi-publik-dhe-rritja-ekonomike/

Komoni, S. (2008). Financat, Pristina.

Krajewski, P., \& Mackiewicz, M.(2005). Fiscal deficit, size of the public sector and investment rate - a panel study. 1-20.

Krajewski, P., \& Obstfeld, M. (1994). International Economics, Theory and Polies, Third Edition. Copyright.

Kryeziu, R.(2013). Development of Public Finanace in the Republic of Kosovo. Thesis PhD. University of Tirana, Faculty of Economics.

Kryeziu, R. (2014). Public Finances, Pristina.

Kryeziu, R. (2009). Foreign Direct Investments in the Republic of Kosovo and Their Impact in Economic Development. International Conference, Management Challenges During the Transition, 28-29 April 2009, Tirana, Faculty of Economics, University of Tirana.

Leccisoti, M. (2000). Lectures on Finance Science, Elite-Publishing House \& Libraries, Tirana.

Meltzer, Allan H., (2010). A History of the Federal Reserve, Volume 2, Book 1, 19511969. Chicago, University of Chicago Press.

Musgrave, R.(1959). The theory of public finance: a study in public economy. McGrawHill, New York.

Mehmeti, F., \& Dragaj, A. (2019). "Fiscal policy in Kosovo and its impact on economic development", Knowledge International Journal, 26(6), 1693-1701.

Mohun P. Odit, K. Dookhan, S. Fauzel. (2010) "The Impact Of Education On Economic Growth: The Case Of Mauritius", International Business \& Economics Research Journal (IBER), 9(8), 141-152. 
Orszag, P. \& Fellow, J. (2004). The Budget Deficit Does It Matter? City Club of Cleveland, July16.

Ricardo, D. (1817). On Principles of Political Economy and Taxation. https://socialsciences.mcmaster.ca/econ/ugcm/3\|l3/ricardo/Principles.pdf

Ristic, Z. \& Jovanoviç, D. (1992). Komparativni fiskalni sistem, Beograd.

Rosen, H. (2003). Public Finance Department of Economics, University Piketon, Altin, Tirana, 2003.

Roubini and Sachs (1989). "Political and Economic Determinants of Budget Deficits", European Economic Review 33 (5): 903-933.

Rowley, C. K. Schneider F. (2010). Readings in Public Choice and Constitutional Political Economy. Springer.

Profeta, P. (2003) Tax Systems and tax reforms in Europe: Public Finance an political economics, SIEP WP 183/2003.

Pavia, January. Rawls, J. (2001), Justice as fairness: A restatement, Cambridge, Mass.: The Harvard University Press.

Selimaj, A. X., Statovci, B., Lokaj, A. S., \& Beqiri, E. (2020). “The Impact of Public Debt in Economic Growth", Academic Journal of Interdisciplinary Studies, 9(4), 177-186. https://doi.org/10.36941/ajis-2020-0072.

Sheikh M. et al. (2010): "Domestic Debt and Economic Growth in Pakistan: An Empirical Analysis", Pakistan Journal of Social Sciences (PJSS), 30 (2) 373-387.

Tanzi, V. (2005) "The Economic Role of the State in the 21st Century", Cato Journal, Cato Institute, 25(3), 617-638.

Tanzi, V. (1999). "Transition and the Changing Role of Government", Finance \& Development, (36)2.

Trotman, D. (1996). Economics of the Public Sector, first published 1996 by, Printed in Malaysia.

Wagnerit, A. (1890). Finanzwisenschaft, Leipzig.

Winer, Stanley L.; Ferris, J Stephen (2003). Searching for Keynes: An Essay on the Political Economy of Fiscal Policy, with Application to Canada, 1870-2000 revised version, CESifo Working Paper, No. 1016, Center for Economic Studies and ifo Institute (CESifo), Munich. 